\title{
Thatcherismin ristiriitainen perintö ja populaarikulttuuri
}

\begin{abstract}
Britannian pääministeri Margaret Thatcherin (1925-2013, pääministerinä 19791990) ympärille syntyi 1980-luvulla runsaasti häntä ja hänen uusliberaalia ideologiaansa vastustavaa kulttuuria, josta suuri osa tuli elokuvan, televisiosarjojen ja populaarimusiikin piiristä. Thatcherismin aika ja 1980-luku näyttäytyvät kuitenkin myös vaurauden, näyttävän muodin, uuden teknologian, median, kapitalismin voittokulun ja seksuaalisten vähemmistöjen poliittisen taistelun vuosikymmenenä. Mielikuva on osaltaan ristiriidassa Thatcherin itsensä peräänkuuluttaman säästäväisyyden, kurinalaisuuden, heteronormatiivisten perhearvojen ja viktoriaanisuuden kanssa. Miten kyseinen perintö asettuu vasten nykypäivän (populaari)kulttuuria? Tämän katsauksen tarkastelemat kolme äskettäin ilmestynyttä elokuvaa - Rautarouva (2011), My Life with Liberace: Behind the Candelabra (2013) ja Soul Boys of the Western World (2014) - käsittelevät kaikki omalla tavallaan uuskonservatiivisuuden ja 1980-luvun ristiriitaista perintöä.
\end{abstract}

Thatcherista äskettäin tehty elämäkertaelokuva Rautarouva (The Iron Lady, Phyllida Lloyd, 2011) pyrki inhimillistämään päähenkilönsä ja silottelemaan niin thatcherismiin kytkeytyviä poliittisia kuin kulttuurisiakin ristiriitoja. Elokuvassa Thatcherista tuli Guardianin kriitikon Peter Bradshaw'n mukaan "Meryl Streepin taitavasti näyttelemä drag queen" (Bradshaw 2012). Thatcherin suhde rahaan, valtaan ja itsekuriin - kapitalismin pyhään kolmiyhteyteen - jäi elokuvassa sivuosaan, kuten myös hänen edustamansa oikeistoradikalismikin. Monet hänen 1980-luvulla masinoimansa kulttuurisodat, kuten 1988 tapahtunut yritys hyökätä homoseksuaalien oikeuksia vastaan Section 28 -lain avulla, olivat yrityksiä kääntää kelloja taaksepäin muuttuvassa maailmassa. ${ }^{1}$ Siksi yksi viime vuosien oudoimpia "trendejä" Britanniassa onkin ollut Margaret Thatcherin hahmon muuntuminen queer-idoliksi nuorten homoseksuaalien konservatiivimiesten keskuudessa (James 2011, 211-227).

Yksi selitys löytynee itse Thatcherin hahmon muuttumisesta fiktiiviseksi. Hänen voimakastahtoinen - aikanaan myös androgyyninä koettu - ja maskuliininen persoonansa synnytti niin vihamielisyyttä kuin ihailuakin: poliittisena keulakuvana hän oli helppo kohde parodioille ja karikatyyreille (kuningatar Viktoriasta raivopäiseen johtajaopettajattareen), jotka kaikki loitonsivat todellista Thatcheria kohti kuvitteellista maailmaa. Lopulta hänen groteski ja burleski kasvokuvansa kelpasi jopa Ison-Britannian pride-kulkueisiin - ilmiö, jonka myötä Thatcher oli monien muiden julkisuuden henkilöiden tapaan liikkunut kuvitteelliselle alueelle ja synnyttänyt itselleen toisen elämän queer-ikonina.

\footnotetext{
1 1960-luvun lopulla hän oli ollut yksi harvoista konservatiivikansanedustajista, jotka kannattivat homoseksuaalisuuden kriminalisoivan lakipykälän kumoamista (Miller 1995, 422-430).
} 

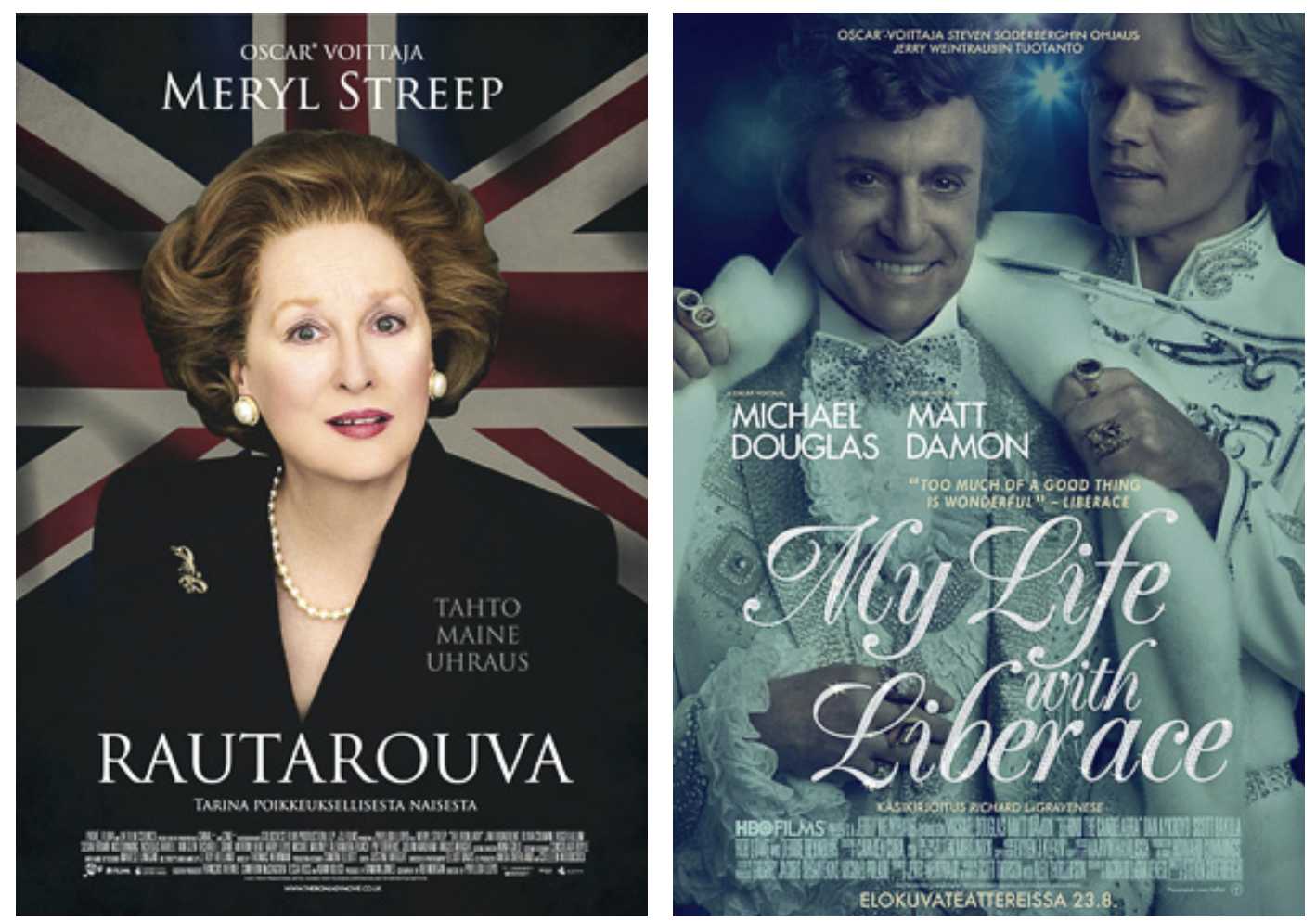

Margaret Thatcherista tehdyssä elämäkertaelokuvassa Rautarouva Thatcherin suhde oikeistoradikalismiin jää sivuosaan. Kuva: ( ) Scanbox Entertainment Finland Oy.

My Life with Liberace -elokuvan keskiössä on viihdepianisti Liberacen bling bling -elämä ja suhde eläinkouluttaja Scott Thorstoniin. Kuva: @ Home Box Office, Inc. / SF Film Finland Oy.

Meryl Streepin luonnehtima viileä drag-ikoni Thatcher, joka näyttäytyi radikaalina naisjohtajana miesten maailmassa, on näin ollen rinnakkainen elokuvan My Life with Liberace: Behind the Candelabra (Steven Soderbergh, 2013) queer-ikonille viihdepianisti Wladziu Valentino Liberacelle (1919-1987, esittäänä Michael Douglas). Elokuva kuvaa Liberacen elämää vuodesta 1977 vuoteen 1984 - ja erityisesti hänen suhdettaan nuoreen eläinkouluttaja Scott Thorstoniin (1959-, esittäänä Matt Damon), josta tulee vähitellen Liberacen rakastaja. ${ }^{2}$

\section{Pula-ajan lapset}

Miksi verrata Liberacea Margaret Thatcheriin? Samaan ikäluokkaan kuuluvina aikalaisina he olivat molemmat 1930-luvun pula-ajan lapsia, jotka palasivat läpi elämänsä kyseisen aikakauden perustavanlaatuisiin kokemuksiin. Thatcherille nämä kokemukset merkitsivät jatkuvaa itsekurin ja säästäväisyyden korostamista, Liberacelle taas jatkuvaa pakoa niukkuudesta ja säädyllisyydestä vaurauden, kuluttamisen, hedonismin ja groteskin ylellisyyden maailmaan, joka oli kuin felliniläinen versio 1980-luvun kulutusjuhlista. Liberacen kuuluisaa mottoa siteeraten "too much

\footnotetext{
2 Elokuva perustuu Thorstonin paljastusromaaniin Behind the Candelabra: My Life with Liberace (yhdessä Alex Thorleifsonin kanssa, 1988).
} 
of everything is wonderful" muuttui 1980-luvun myötä muotoon "too much of everything is never enough".

Itse thatcherismin perintö - alkuperäisistä tavoitteistaan riippumatta - määrittyy tänä päivänä usein juuri näiden sloganien kautta. Thatcheriä ja Liberacea yhdisti urillaan myös populismi: esteettinen ja poliittinen. Kun Liberace imarteli yleisöään tavaramerkeikseen muodostuneen flyygelin ja sen päälle asetetun kimaltelevan kynttelikön säihkeessä, tämä klassisena pianistina uransa aloittanut ja vaatimattomista oloista Wisconsinin Milwaukeesta puolalaisen siirtolaisperheen vesana julkisuuteen ponnistanut mies viestitti yleisölleen provokatiivisella tavalla, että yleisesti hyväksytyt ja ylläpidetyt esteettiset ja kulttuuriset erot eivät merkinneet enää mitään. ${ }^{3}$ Näin Liberace toteutti urallaan myös Itä-Euroopasta peräisin olevan amerikkalaisen kulttuurin demokratisoijan Andy Warholin ajatusta: "Everything is good."

Thatcherin isä oli säästäväisyyttä alleviivaava metodisaarnaaja, jonka viesti osui erittäin otolliseen maastoon juuri 1930-luvun pulakaudella. Ristiriitaisella tavalla Thatcheria voi kuitenkin pitää niin kasinokapitalismin synnyttäänä kuin viktoriaanisen itsekurin puolestapuhujana aikana, jolloin kerskakulutus ja kaupallinen media edistivät kulutusyhteiskunnan voittokulkua. Lapsuuden opit saivat hänet tavoittelemaan poliittista utopiaa, joka olisi antiteesi sodanjälkeiselle hyvinvointivaltion utopialle. Jos Liberace rikkoi esteettisen konsensuksen, Thatcher rikkoi toisen maailmansodan jälkeisen poliittisen konsensuksen väittämällä populistisesti, että jokaisella on velvollisuus hoitaa (taloudelliset) asiansa yksin ilman valtion tukea ja että valtion kukkaroa on hoidettava, niin kuin kotiäiti hoitaa omaansa.

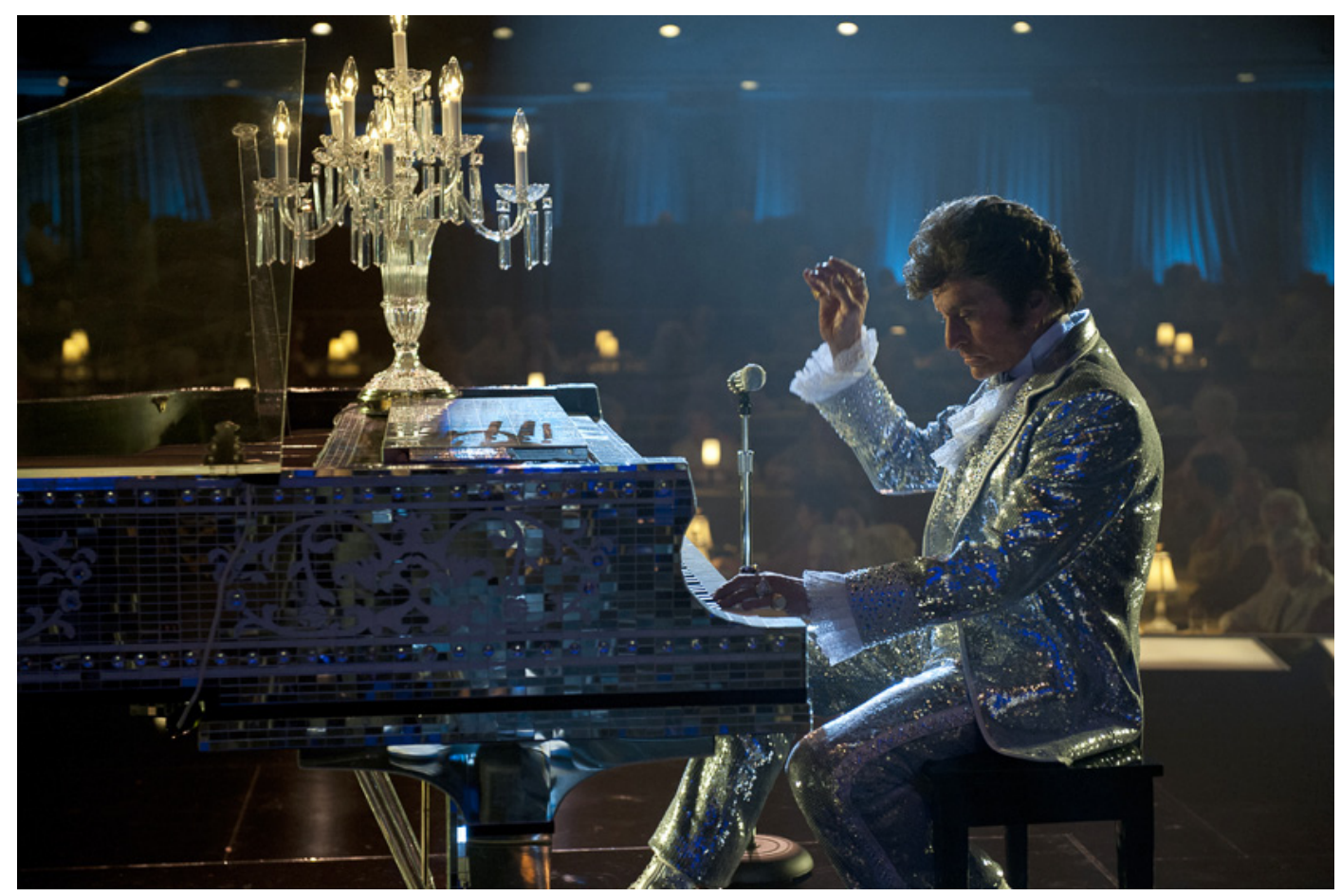

Liberacen tavaramerkki - flyygeli ja sen päälle asetettu kynttelikkö - saavat näkyvän osan My Life with Liberace -elokuvassa. Kuva: ( ) Home Box Office, Inc.

${ }^{3}$ Esitykseen kuului oleellisesti kieli poskessa kujeileva mutta samalla arvokkaan viihteellinen repertuaari, jota hän itse kutsui klassiseksi musiikiksi, josta on jätetty tylsät kohdat pois (Asbury Pyron 2000). 
Samaan tapaan kuin Thatcherin omaksumat populistiset sloganit - ja hokemiin perustuva uuskonservatiivinen ajattelu - yksinkertaistivat monimutkaisia yhteiskunnallisia kysymyksiä, Liberacen tapa kiistää kulttuurin hierarkiat tekivät hänestä todellisen demokraattisen massakulttuurin edustajan. Hänen edustamansa campestetiikan läpimurto 1980-luvulla oli yhtä vallankumouksellista kuin Thatcherin ajama uusi yhteiskunnallinen ajattelu. Yhdessä he antoivat kylmän sodan ajan jälkeiselle kapitalismille kasvot: Liberace camp-hengessä ja Thatcher uusviktoriaanisuuden hengessä. Rautarouva ja My Life with Liberace muuttuvatkin tässä yhteydessä alkuperäänsä mielenkiintoisemmiksi elokuviksi: millaista vaurastumiseen, rahan kaikkivoipaisuuteen ja materiaaliseen maailmankuvaan liittyvää vallankumousta niiden päähenkilöt lopulta edustivat?

\section{Bling-bling trickster ja rautarouva}

Heti My Life with Liberacen avauskohtaus Liberacen konsertista Las Vegasissa kuvaa "hiljaista vallankumousta", jossa Liberace on korkean ja populaarin välisen rajan subversiivinen rikkoja. Laulattaessaan ja naurattaessaan banaalilla tavalla yleisöään palatsikulisseissa hän kiteyttää "hyvän huonon maun" fantasian. My Life with Liberacessa kamera panoroi usein Liberacen asuntojen suureellista kitschiä (Liberacen omien sanojen mukaan "palatial kitschiä"), joka - tuodessaan mieleen Versaillesin peilisalit - on kuin Liberacen persoonan lavastettu jatke.

Rautarouvan kehystarinana taas on paronitar Thatcherin elämän ehtoopuolen yksinäiset hetket, joiden keskellä hän kuvittelee keskustelevansa kuolleen miehensä, liikemiesmiljonääri Dennis Thatcherin (1915-2003, esittäjänä Jim Broadbent) kanssa. Hauraan oloinen ja muistoihinsa eksyvä Thatcher käy läpi elämäänsä takautumissa. Takaumat kuvaavat Thatcherin poliittisen uran käännekohtia ja taisteluja sekä suhdetta kannustavaan aviomies Dennisiin, josta Broadbent rakentaa näyttelijäntyöllään perusbrittiläisen "jolly good fellow'n". Meryl Streepin näyttelijäntyö Thatcherina puolestaan välttää Thatcherista tehdyt aiemmat karikatyyrit ja kuvaa hyvin hienovaraisesti tämän pimeää puolta: nuukuutta, vallanhimoa sekä pyrkimystä nöyryyttää ja pitää hallituksen miespuolisia ministereitä varpaisillaan. Thatcherin uran kohokohdat ja poliittiset taistelut kuvataan miltei herooisin sävyin, mikä pistää miettimään ohjaaja Phyllida Loydin tarkoitusperiä. Onko ollut tarkoitus tehdä Thatcheristä elokuvan nimen mukainen sankaritar, joka saa ylleen myös kodikkuuden kaavun, ja välttää viimeiseen asti hänen uraansa liittyviä poliittisia ja kulttuurisia ristiriitoja?

\section{Tavara, työ, shoppailu ja kapitalismi}

Thatcher on kylmän sodan päättymisen jälkeen symboloinut Ronald Reaganin tavoin konservatiivista herooisuutta ja glamouria, joihin on kiteytynyt länsimaisen demokratian ja vapauden arvot. Thatcherin perintö on myös päivitys puritanismin sitkeimmästä uskomuksesta. Tämän uskomuksen mukaan ihmistä motivoi eräänlainen niukkuuden ylläpitämä itsekkyys, joka saa yhteiskunnan pyörät pyörimään. Kun Rautarouvassa Thatcher vielä eläkkeellä ollessaankin murehtii maitopurkin hinnan nousua ja tiskaa palvelijan vastusteluista huolimatta kahvikuppinsa itse, Liberace toimii toisessa universumissa: hän tuhlaa estottomasti rahojaan ja ympäröi itsensä tuittupäisillä miespalvelijoilla, joiden kanssa hän voi toteuttaa (homo)seksuaalisia fantasioitaan. Rinnakkain luettuna elokuvat asettuvat kuin jälkithatcheriläisen ajan ristikuviksi: thatcherismin niukkuuden voitto ovat uutiskuvat jatkuvista julkisen talouden leikkauksista, kun taas Liberacen yltäkylläisyyden maailma toistuu viih- 
demedian loputtomissa kuvauksissa etuoikeutettujen oikukkaasta ja mielikuvituksellisesta rahankäytöstä.

Kumpikaan elokuva ei varsinaisesti kommentoi yhteiskunnallista todellisuutta vaan esittää sen päähenkilöidensä erityisten persoonallisuuksien osina. Kun Rautarouvassa Thatcher on nuivalla tavalla patrioottisen ylpeä Napoleonin aikanaan briteille antamasta pilkkanimestä "kaupanpitäjien kansakunta", edustaa Liberacen tyyli taas eräänlaista nykypäivän oligarkkien luksusta, jolla on juurensa imperiaalisessa kulttuurissa.

\section{Camp-sensibiliteetin vastakulttuurisen merkityksen muutos}

Luksuksen kiehtovuus on sekä yhdistävä että erottava tekijä Margaret Thatcherin ja Liberacen välillä. Vaikka kummankin tausta on pula-ajan kokemuksissa ja uskonnollis-autoritäärisessä kasvatuksessa (Campbell 2001, 1-2), menneen ajan (Hollywood, kuninkaalliset, kirkolliset seremoniat) glamour ja sen kiihtyvä kierrättäminen 1980-luvulta alkaen ovat tärkeä osa heidän historiallista taustaansa. Tässä yhteydessä heritage-kulttuuria saattoi alusta asti tulkita niin osana camp-henkistä sensibiliteettiä kuin uuskonservatiivista ideologiaakin.

My Life with Liberacessa Liberace paljastaa rakastajalleen, kuinka hän on halunnut luoda asunnoistaan vastineet Baijerin kuninkaan Ludvig II:n (1845-1886) palatseille. Katolisuus ja rojalismi luonnehtiikin hänen maailmankuvaansa: paavi Pius XII:n tapaaminen ja esiintyminen Elisabeth II:lle vuonna 1960 kuninkaallisessa varieteeshow'ssa olivat Liberacen uran huippuhetkiä. Thatcherismin anglo-saksisessa protestantismissa tällainen yltäkylläisyys yhdistyi usein dekadenttiin eurooppalaisuuteen. Katolinen koreilevuus oli epäilyttävää kalvinistisen ankaruuden näkökulmasta. Rautarouvassa Thatcherin romantiikan nälkäinen puoli paljastuu, kun hän löytää vanhan suosikkivideon musikaalista Kuningas ja minä (King and I, Walter Lang, 1956). Musikaali kertoo kolonialistiseen aikaan sijoittuvan tarinan englantilaisen yksityisopettajan (Deborah Kerr) ja Siamin kuninkaan (Yul Brynner) välisestä romanssista.

Hollywood-musikaalien kitschin lukeminen vastakarvaan on pitkään ollut yksi gayja camp-estetiikkojen lähtökohdista. Thatcherin hahmon queer-luenta selittyy myös osin tätä kautta. Thatcherin viktoriaanisuutta huokuva persoona oli outo ilmestys 1980-luvun populaarikulttuurisessa ilmastossa. Se ja hänen vallankumouksellinen konservatiivisuutensa oli kuitenkin subversiivistä samaan aikaan kuin Liberacen performanssi subversoi amerikkalaista menestystä ja sen symboleja - koruja, sormuksia, kalliita autoja ja jalokivillä koristeltuja esiintymisturkkeja. Subversiivisuus yhdistää Liberacen bling bling -performanssin ja Thatcherin queer-hahmon toisiinsa ja 1980-lukuun. Sekä konservatiivisuuden että liberalismin luonne on kuitenkin muuttunut noista ajoista. Jos Liberacen aiempi subversiivinen radikaalius, jonka avulla hän kritisoi amerikkalaista patriarkaalista, kapitalistista ja heteronormatiivistä ideologiaa (Thompson Drewal 1994, 149-181), on tänä päivänä aggressiivisen yksipuolisesti todistelemassa saman ideologian voittokulkua, voi myös Thatcherin kaltainen konservatiivipoliitikko muuttua queer-ikoniksi, jonka radikaali tapa puolustaa angloamerikkalaista taloudellista yksilönvapautta kasvaa osaksi laajempaa yksilönvapauksien puolustamista. 


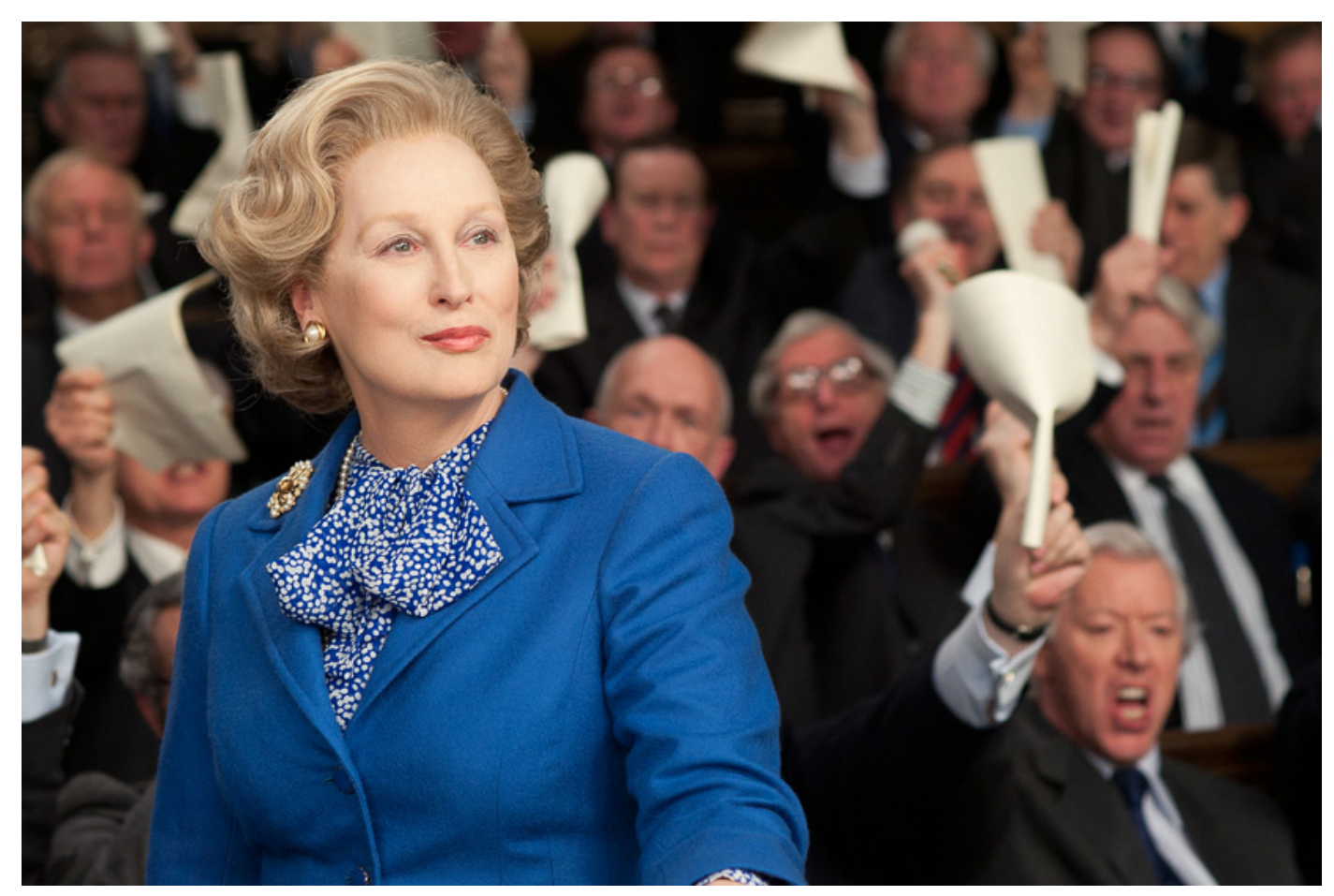

Meryl Stryypin näyttelijänsuoritus Thatcherina oli elokuvakritiikin mukaan omiaan korostamaan hahmon campmaisuutta ja maalasi Rautarouvasta kuvan "drag queenina". Kuva: () Scanbox Entertainment Finland Oy.

\section{Thatcherismin biitti tanssilattialla}

Myös 1980-luvun alun brittiläinen uusromanttinen nuorisokulttuuri hyödynsi ristiriitaista asetelmaa. Sen rooli- ja ristiinpukeutumisessa toteutui niin Liberacen yliampuva estetiikka kuin uuskonservatiivinen vanhan tyylin ja sääty-yhteiskunnan ajan glamourin ihailukin. Lontoon 1980-luvun alun klubimaailmassa thatcheristinen idea toteutui uudentyyppisessä yrittäjyydessä, jossa tee-se-itse-pohjalta liikkeelle lähteneet nuoret enterprenöörit loivat itse imagonsa, tähtensä, musiikkinsa ja viihtymisensä puitteet. Tästä maailmasta nousi myös lontoolaisyhtye Spandau Ballet, joka menestyksekkään comebackin vuonna 2009 toteuttaessaan sai heti osan brittitoimittajista muistelemaan Thatcherin ajan traumaattisia vaiheita. The Guardianin toimittaja Michael Hann reagoi comebackiin erityisen vihamielisesti toteamalla: "Spandau Ballet on tyhjän historiasta ammentavan tyylikkyyden ruumiillistuma, ainoana pyrkimyksenään näyttää hyvältä tanssilattialla. Spandau Ballet on thatcherismin soundi tallennettuna vinyylille". (Hann 2009.)

Miksi bändiä on tulkittu thatcherismin edustajaksi? Se toteutti urallaan 1980-luvun menestystarinan - työväenluokkaisten lontoolaispoikien maailmanvalloituksen -, joka on ikiaikainen populaarimusiikin historiassa. Kuitenkin yhdistyneenä ajan mediakulttuurin tapaan hyödyntää taidetta, mainosestetiikkaa, narsismia, konsumerismia, menestystä ja menneisyyden kulttuuristen merkkien kierrätystä varhaisella neoliberaalilla markkinapaikalla tuo sama tarina asetti bändin väistämättä osaksi thatcherismin ideologiaa. 


\section{Lontoon Islingtonin työläiskortteleista St Tropez'n rannoille}

Spandau Ballet'n comebackin kunniaksi valmistunut dokumentti Soul Boys of the Western World (George Hencken, 2014) käy melko perinteisin keinoin läpi yhtyeen uran 1970-luvun lopulta tähän päivään mutta sivuaa myös 1980-luvun brittiläisen popmusiikin suhdetta aikakauden thatcheristisiin virtauksiin: juppeihin, kulutuskulttuuriin, uuteen mediaan ja brittiläiseen heritage-kulttuuriin. Yhtyeen uran alkuvaiheet rinnastuvat dokumentissa ajan uutisfilmeihin: Thatcher heiluttamassa harjaa konservatiivien puoluekokouksessa ja pyyhkimässä "sosialismin lopullisesti pois Britanniasta", ylipukeutuneet nuoret jonottamassa Spandau Ballet'n varhaiseen kantapaikkaan Lontoon Blitz-klubille ja konservatiivien kannattajat kauhistelemassa roskakuskien lakon vuoksi kadulle kasattuja jätesäkkejä. Samalla se kuvaa bändin alkuvaiheita 1970-luvun Britannian valkoisessa soulboy-kulttuurissa, joka oli yksi työväenluokkainen reaktio keskiluokkaisen nuorison suosimaa progressiivista rockia kohtaan. Tavoittamattomissa olevan tyylikkyyden, luksuksen ja kulutuksen ihailu oli samalla jatkoa toisen maailmansodan jälkeisen ajan nuorisokulttuurien Amerikan ihailulle. Ihailun ytimessä oli kuitenkin myös omalaatuisen kotikutoista brittiläistä patriotismia ja anti-amerikkalaisuutta: britit osasivat mielestään stailata amerikkalaista musiikkia, muotia ja nuorisotyylejä paremmiksi. Siksi myös soulboy-kulttuuri - monien muiden brittiläisten nuorisotyylien tapaan - piti sisällään elitismiä, joka purkautui esiin uusromantikkojen retrotyyleissä ja loputtomassa erottautumisvarustelussa.

Spandau Ballet'n matka maailmanmaineeseen pop-funk-yhtyeenä alkoi juuri uuden tanssimusiikin ympärille kiinnittyneestä lontoolaisesta klubikulttuurista, joka kekseliäästi ja yritteliäästi keskittyi nuorisotyylien markkinointiin. Spandau Ballet'n lauluntekijä Gary Kempin sanoin: "halusin vain värjätä tukkani ja olla ajattelematta Margaret Thatcheria". Pelkästään tämä alleviivattu epäpoliittisuus sai osan musiikkimediasta epäluuloiseksi yhtyeen tarkoitusperien suhteen.

Tämän todellisuuden keskellä uusi pop halusi luoda tyylimanifestin 1980-lukua varten: ohjelman, jonka avulla brittiläinen musiikki- ja muotiteollisuus yltäisivät uudestaan 1960-luvun menestykseen. Tämä merkitsi myös punkin hengessä luotua rajua mutta taiteellista imagoa: viimeistä Nurnbergin oikeudenkäynnissä tuomittua natsi-rikollista Rudolf Hessiä Berliinissä säilyttänyt Spandaun vankila oli nimenä tarpeeksi provokatiivinen tähän tarkoitukseen. Nimi pyrki samaan shokeeraavuuteen kuin musikaali Cabaret (Bob Fosse, 1971), joka kuvasi Weimarin ajan Berliiniä ennen natsien valtaannousua. Spandau Ballet'n päästyä kuukaudeksi esiintymään St. Tropez'n klubeille ja eurooppalaisen jetsetin leikkikentälle bändin toive saada kosketus eksoottiseen ja dekadenttiin eurooppalaiseen glamouriin toteutui: "Paikka oli täynnä vanhan koulukunnan tyyliä kulttuurikohteineen ja seurapiireineen, sitä, mitä kohti aina kurkotimme."

\section{"Better living through Thatcher years"}

Soul Boys of the Western World kertaa tarinaa siitä, kuinka paremman elämän ja laadukkuuden tavoittelu on ollut aina osa brittiläisiä työväenluokkaisia nuorisokulttuureja. Siksikö juuri thatcherilaisella 1980-luvulla nuorisokulttuurit siirtyivät lopullisesti kaduilta muotihuoneisiin, mainostoimistojen suunnittelupöydille ja musiikkivideoihin? Dokumentissa todetaan, että englantilainen dandyismi oli alun perin salaliitto aristokratiaa vastaan: dandyismin kautta väitettiin, että kaikki herrasmiehet ovat tasaarvoisia. Korkeakulttuurin popularisoiminen massoille kiehtoo tässäkin yhteydessä. Myös tietoisuus Spandau Ballet'n populaarikulttuurisesta merkityksestä on saanut 
ystävät ja enterprenöörit dokumentoimaan yhtyeen uran kaitafilmille ällistyttävällä tarkkuudella. Myös media oli aikanaan television kulttuuriohjelmia myöten ahkerasti yhtyeen kintereillä jo ennen sen ensimmäistä listahittiä. Dokumentti kuvaakin 1980-luvun alun ilmapiirissä olevaa visuaalis-kulttuurisen vallankumouksen tuntua, joka symboloi Thatcherin jälkiteollisen yhteiskunnan palvelutalouden läpimurtoa.

Myös Spandau Ballet'n musiikillinen kehitys seuraa thatcherismin eri vaiheita. Vielä kesällä 1981 - työttömyyden saavuttaessa 44 vuoteen korkeimman lakipisteen Britanniassa ja prinsessa Dianan ja Charlesin viettäessä häitään suurkaupungeissa riehuvien mellakoiden keskellä - Spandau Ballet kommentoi ympäröivää yhteiskuntaa singlellään Chant No.1 (I Don't Need This Pressure On), jonka funk-rytmi viesti vielä katujen anti-thatcherilaista angstia. Pari vuotta myöhemmin Thatcherin tultua Falklandin sodan ansiosta valituksi uudelleen pääministeriksi Spandaun singlet (True ja Gold, 1983) viestittävät kilpailun, itselleen uskollisena pysymisen ja voittamisen retoriikkaa. Tämän jälkeen yhtyeen supertähteyden kiitorata oli valmiiksi kiillotettu: esiintymiset Live Aidissa, kiertue Australiassa ja suosio Kaukoidässä tekivät heistä yhden 1980-luvun ikonisista yhtyeistä. ${ }^{4}$

Kaikesta huolimatta dokumentti kieltäytyy häveliäästi pohtimasta, missä määrin Spandau Ballet oli thatcherismin ruumiillistuma. Gary Kemp on monesti painottanut yhtyeen työväenluokkaisia juuria ja kokemusmaailmaa: tämä tuodaan myös dokumentissa esiin työväenluokkaisena toverihenkenä ja "jätkäilynä". Kempin mukaan Spandau Ballet on thatcheristinen vain tarkoitushakuisten keskiluokkaisten vasemmistotoimittajien ajatuksissa. Dokumentti ei myöskään puutu yhtyeen mainetta pitkään rasittaneen laulaja Tony Hadleyn avoimeen Thatcherin kannatukseen: Hadley oli konservatiivien puoluejäsen ja kuului 1980-luvulla pieneen vähemmistöön brittiläisiä rock-tähtiä, jotka esittivät Thatcheriä myötäileviä ajatuksia (Long 2012).

Lopulta yhtyeen ura osoittautui suunnilleen yhtä pitkäksi kuin Thatcherin kolme pääministerikautta 1979-1990. Dokumentti väittää Spandau Ballet'n olleen jotain ainutlaatuista ja erityistä, joka saattoi tapahtua vain 1980-luvun poikkeuksellisissa oloissa. Todellisuudessa sen ainutlaatuisuus oli hyvin nurkkakuntaista, ja se edusti viihteellistä brittiläisen tanssimusiikin lajia, jolle on ollut etupäässä tilausta vain saarivaltakunnan tanssilattioilla. Ainutlaatuisemmaksi Spandaun tekee se, että yhtyeen taidekouluorientoitunut flirtti "vanhan hengen" ja äärioikeistolaisen kuvaston kanssa - brittiläinen uusfasistinen lehti Bulldog ylisti Spandauta "hienoksi lihaksikkaan pohjoisen taiteen" lähettilääksi (Reynolds 2005, 327) - oli eturintamassa tekemässä fasistisesta kuvastosta muodikasta populaarikulttuurissa. Nyt kun Spandaun laiska valkoisen miehen funk on pääasiassa unohdettu Euroopassa (Britanniaa lukuunottamatta) mutta uusthatcherismi ja uuskonservatiivisuus eri muotoineen keräävät edelleen kannatusta, on Spandaun alkuaikojen flirtti Euroopan "vanhan hengen" kanssa muuttunut yhtä todeksi kuin Liberacen flirtti mammonan symbolien kanssa.

Katsaus on osa Koneen säätiön rahoittamaa tutkimushanketta "Thatcherism, Popular Culture and the 1980s".

\footnotetext{
4 Spandau Ballet'n Hong Kongissa kuvattu musiikkivideo Highly Strung (1984) on kuin ylistyslaulu sille menestyksen huumalle, jota Lontoon Cityn nuoret pankkiirit kävivät harjoittelemassa Hong Kongin pankkimaailmassa 1980-luvulla ennen siirtymistään Cityn finanssitavaratalojen palvelukseen.
} 


\section{Lähteet}

Asbury Pyron, Darden (2000) Liberace: An American Boy. Chicago: The University of Chicago Press.

Bradshaw, Peter (2012) “The Iron Lady - review". The Guardian 5.1.2012, <http://www.theguardian. com/film/2012/jan/05/the-iron-lady-film-review > (linkki tarkistettu 1.3.2016).

Campbell, John (2001) Margaret Thatcher, vol.1: The Grocer's daughter. Lontoo: Pimlico.

Hann, Michael (2009) “Spandau Ballet: The Sound of Thatcherism”. The Guardian music blog 25.3.2009, <http://www.theguardian.com/music/musicblog/2009/mar/25/spandau-ballet-thatcherism> (linkki tarkistettu 1.3.2016).

James, Dominic (2012) "'One of Us': The queer afterlife of Margaret Thatcher as a gay icon". International Journal of Media E Cultural Politics, vol.8:2-3 (2012), 211-227.

Long, Pat (2012) “Why are there so few right-wing rock stars?”. New Statesman 8.3.2012, <http://www. newstatesman.com/blogs/cultural-capital/2012/03/rock-music-britain-nme> (linkki tarkistettu 1.3.2016).

Miller, Neil (1995) Out of the Past. Gay and Lesbian History from 1869 to the Present. New York: Vintage Books.

Reynolds, Simon (2005) Rip it Up and Start Again. Post-punk 1978-1984. Lontoo: faber \& faber.

Thompson Drewal, Margaret (1994) "The Camp Trace in Corporate America - Liberace and the Rockettes at Radio City Music Hall". Teoksessa Moe Meyer (toim.) The Politics and Poetics of Camp. Lontoo: Routledge, 149-181. 